\title{
VW-Aero Engine Cylinder Head Cooling Efficiency Investigation ${ }^{\dagger}$
}

\author{
Rapee Ujjin *, and Choosak Ngaongam $\ddagger$ \\ Department of Aviation Maintenance Engineering, College of Engineering, Rangsit University, \\ Pathumthani 12000, Thailand; choosak.ng@gmail.com \\ * Correspondence: rapee.u@rsu.ac.th \\ + Presented at the Innovation Aviation \& Aerospace Industry - International Conference 2020 (IAAI 2020), \\ Chumphon, Thailand, 13-17 January 2020. \\ $\ddagger$ These authors contributed equally to this work.
}

Published: 30 December 2019

\begin{abstract}
Light sport aircraft builders widely construct experimental aircraft for their personal enjoyment for both building and flying purposes. A variety of engines are used as powerplants for their aircraft. The Volkswagen (VW) automotive engine is one of the most reliable engine conversions for amateur-built aircraft. The aim of this paper is to investigate the cylinder head temperature of the VW-Aero conversion engine during flight conditions by using CFD. The models of the front and rear cylinder barrels include a cylinder head which is constructed with the addition of a baffle plate and air inlet design shape based on internal air flow patterns. The simulations were performed at a velocity of between $50-100 \mathrm{kt}(58-115 \mathrm{mph})$ at a flying altitude of 6,000 feet as per typical flight conditions. The results showed that the rear cylinder lacked cooling air because it was obstructed by a front cylinder. The rear cylinder encountered heat soak conditions which resulted in higher temperature when compared with what the front cylinder experienced. At a velocity of below $80 \mathrm{kt}(92 \mathrm{mph})$, the incoming air velocity through the engine air duct was inadequate to maintain the engine cylinder's head temperature so that it rises above a normal operating temperature range. At a velocity of above $80 \mathrm{kt}(92 \mathrm{mph})$, the internal baffle plate was capable of feeding air through the controlled path between baffle plate and cylinder fin, which consequently resulted in a controllable engine cylinder barrel and head temperature to be within the normal operating temperature range. The aircraft flying at a velocity of less than $80 \mathrm{kt}(92 \mathrm{mph})$ and equipped with a VW engine would be likely to experience an overheated engine problem due to insufficient cooling air.
\end{abstract}

Keywords: Experimental Aircraft; Engine; Volkswagen; CFD; Baffle plate

\section{Introduction}

The using of automotive conversion engine in an experimental aircraft has been widely used as an alternative engine of standard aircraft engine. Among experimental aircraft builders, Volkswagen (VW) automotive conversion engine was the famous choice for amateurs to build their own aircraft. Being an opposed cylinder configuration, $\mathrm{VW}$ engine is among automotive engine to be converted as it is closest to standard aircraft engine. VW engine was the fifth choices next to Lycoming (1st, 2nd and 3rd) and Continental (4th) engine for homebuilders' choice from Federal Aviation Administration (FAA) engine data report (2000). Bingelis admitted that VW engine was the top contender to be the most popular automotive engine for amateur-built aircraft. He also stated that it was continuing of the increasing numbers of homebuilt aircraft using VW engine [1].

The major advantage for VW engine is the primary cooling system which is an air cooled. The cooling efficiency of the engine is relied on the compressed air from belt-driven fan passing through 
shroud and baffle plate then the cylinder head and barrels [2,3]. By removing fan to suit aircraft application, new baffle plates are needed for the engine to provide air cooling path for engine cooling system [4]. Kern revealed that more than hundred different experimental designs were using VWbase engine for their flying machine including motorgliders, powered parachutes, gyroplanes and plans-built aircraft [5]. He also pointed out that suitable VW power for aircraft was between 60-85 hp power rating.

Parker designed Teenie Two aircraft since 1969 which firstly utilized 1200 cc (42 hp) VW engine. The cruising speed achieved $110 \mathrm{mph}$. Monnett designed Sonerai I aircraft in 1970 particularly to enter Formula- $\mathrm{V}$ air racing event which was only for aircraft using VW air-cooled engine upto 100 cu.in $(1600 \mathrm{cc})$. Sonerai II was then designed to be a 2-seater version of Sonerai I. Hummel introduced an affordable Hummel H-5 aircraft in 2002 and Ultracruiser Plus aircraft in 2010 predominantly using VW-engine [6]. In 2010, Thatcher also designed and built his own aircraft, Thatcher CX-4 which was practically inexpensive to build by using basic tools at home garage [7]. The CX-4 was followed by CX-5 design which accommodated 2 people onboard with $85 \mathrm{hp} \mathrm{VW-engine} \mathrm{[8,9].} \mathrm{AeroVee} 2.1$ engine produced $80 \mathrm{hp}$ for Sonex, Waiex, Xenos and Onex aircraft which were also designed by Monett $[10,11]$.

Spangler reported on Clagg's CH701 aircraft which used VW-engine with reduction belted drive for his engine [12]. Clagg had flown his aircraft and encountered overheat problem especially during climbing. The CH701 aircraft was designed for short take-off and landing (STOL) purpose which had cruising speed of $70 \mathrm{kt}(80 \mathrm{mph})$. His engine was removed for repairing due to heated problem twice then replaced with other choice of engine recommended from the designer.

Pietrykowski and Tulwin [13] had analyzed the effectiveness of air cooling system of 18 cylinder double row radial aircraft engine by using CFD simulation. They found that the cooling capability depended on surrounding geometries which were cylinder head fin size, area and channel between fin. It is advisable to maximize the local air flow velocity between fins to improve cooling efficiency.

The aim of this paper is to investigate cooling efficiency of Volkswagen automotive conversion engine in experimental aircraft by using CFD simulation of cylinder head and barrel model including internal baffle plates with boundary condition of airspeed between 50-100 kt (58-115 mph).

\section{VW-Aero Conversion Engine}

The conversion needs some modifications of engine mounting and crankshaft end for propeller installation which requires basic tools and ordinary manufacturing process $[14,15]$. At the present, there are numbers of VW-Aero engine conversion specialists which are supplying parts and complete engine ready for installation as shown in the Table 1 below.

Table 1. List of Volkswagen conversion engine models and suppliers [16].

\begin{tabular}{ccc}
\hline Manufacturer & Engine Model ${ }^{\mathbf{1}}$ & Engine Horsepower (hp) \\
\hline AeroConversions (AeroVee) & $2100 \mathrm{cc}$ & 80 \\
\hline \multirow{3}{*}{ Great Plains Aircraft Supply } & $1835 \mathrm{cc}$ & 65 \\
& $1915 \mathrm{cc}$ & 69 \\
& $2180 \mathrm{cc}$ & 76 \\
& $2276 \mathrm{cc}$ & 80 \\
\hline Hummel Engines & $1600 \mathrm{cc}$ & 50 \\
& $1835 \mathrm{cc}$ & 60 \\
& $1915 \mathrm{cc}$ & 65 \\
& $2180 \mathrm{cc}$ & 76 \\
\hline Motorav Aircraft Engines & $2400 \mathrm{cc}$ & 85 \\
\hline Revmaster Aviation & $2400 \mathrm{cc}$ & 85 \\
\hline
\end{tabular}

${ }^{1}$ Normal aspirated engine, carbureted induction system, direct drive. 
Being quite relatively limited power output, therefore only specific aircraft models successfully adopted VW engine as the main choice of the engine for their aircraft designs. Table 2 is showing light sport aircraft that have been originally designed with VW-Aero engine as a powerplant. These all aircraft were under experimental category aircraft which the structure were constructed from aluminum alloy except only Sonerai I and II aircraft which fuselage was tube and frame construction.

Table 2. List of light sport aircraft using Volkswagen conversion engine [17].

\begin{tabular}{cccccc}
\hline \multirow{2}{*}{ Aircraft } & \multirow{2}{*}{ VW-Engine (hp) $^{\mathbf{1}}$} & \multirow{2}{*}{ Number of Seat $^{*}$} & & \multicolumn{3}{c}{ Speed $^{\mathbf{1}}(\mathbf{m p h})$} \\
\cline { 4 - 6 } & & 1 & Maximum & Cruising & Stall \\
\hline Teenie Two & $42-60$ & 1 & 200 & 110 & 48 \\
Sonerai I & $60-80$ & 2 & 200 & 150 & 55 \\
Sonerai II & $60-80$ & 1 & 135 & 120 & 55 \\
Hummel H5 & $60-85$ & 1 & 135 & 125 & 41 \\
Ultracruiser Plus & $60-85$ & 1 & 135 & 125 & 36 \\
Thatcher CX4 & $55-80$ & 2 & 120 & 110 & 48 \\
Thatcher CX5 & 85 & 2 & 150 & 130 & 40 \\
Sonex-B & 80 & 2 & 150 & 130 & 40 \\
Waiex-B & 80 & 2 & 120 & 100 & 44 \\
Xenos-B & 80 & 1 & 155 & 135 & 45 \\
Onex & 80 &
\end{tabular}

${ }^{1}$ At mean sea level.

\section{3D Simulation}

Cylinder head and barrel of VW-Aero engine model were constructed with external shroud and internal baffle plate by using SolidWorks software. The cylinder head and barrel geometries were taken from VW-Aero $2180 \mathrm{cc}$ engine. The simulations were performed with an external flow analysis at $6000 \mathrm{ft}$ conditions as shown in Table 3.

Table 3. Boundary conditions and values for 3D simulation.

\begin{tabular}{ccc}
\hline Boundary & Value & Unit \\
\hline Air density $^{1}(\rho)$ & 1.0269 & $\mathrm{~kg} / \mathrm{m}^{3}$ \\
Air pressure $^{1}(\mathrm{p})$ & $8.1494 \times 10^{4}$ & $\mathrm{~N} / \mathrm{m}^{2}$ \\
Air viscosity $^{1}(\mu)$ & $1.7324 \times 10^{-5}$ & $\mathrm{~kg} / \mathrm{m} \cdot \mathrm{s}$ \\
Air temperature $^{1}(\mathrm{~T})$ & 276.46 & $\mathrm{~K}$ \\
\hline
\end{tabular}

${ }^{1}$ At $6000 \mathrm{ft}$.

\subsection{CFD Modelling}

\subsubsection{Engine Cylinder Barrel and Head Model}

The full scale cylinder head and barrel had been modeled and assembled together covered with shroud and internal baffle plate. Only 2 cylinder assemblies from one side of the engine were simulated. Figure 1 is showing model assemblies in the simulation. The airspeed in simulation was between $50-100 \mathrm{kt}$. The normal operating temperature range of VW-Aero engine was $180-190^{\circ} \mathrm{C}$. The maximum temperature was $240^{\circ} \mathrm{C}$ [4]. At the beginning of the simulation, a constant temperature of cylinder head and barrel were set to $180^{\circ} \mathrm{C}$ for normal operation and $240{ }^{\circ} \mathrm{C}$ for overheat condition. Cylinder head and barrel were assigned with cast aluminum and cast steel properties respectively. Table 4 is showing engine working condition at $75 \%$ of full power which was typical cruising condition at 2950 RPM with normal stoichiometric air-fuel ratio. Figure 2 are showing model assembly for simulation. 
Table 4. Engine working condition at $75 \%$ power.

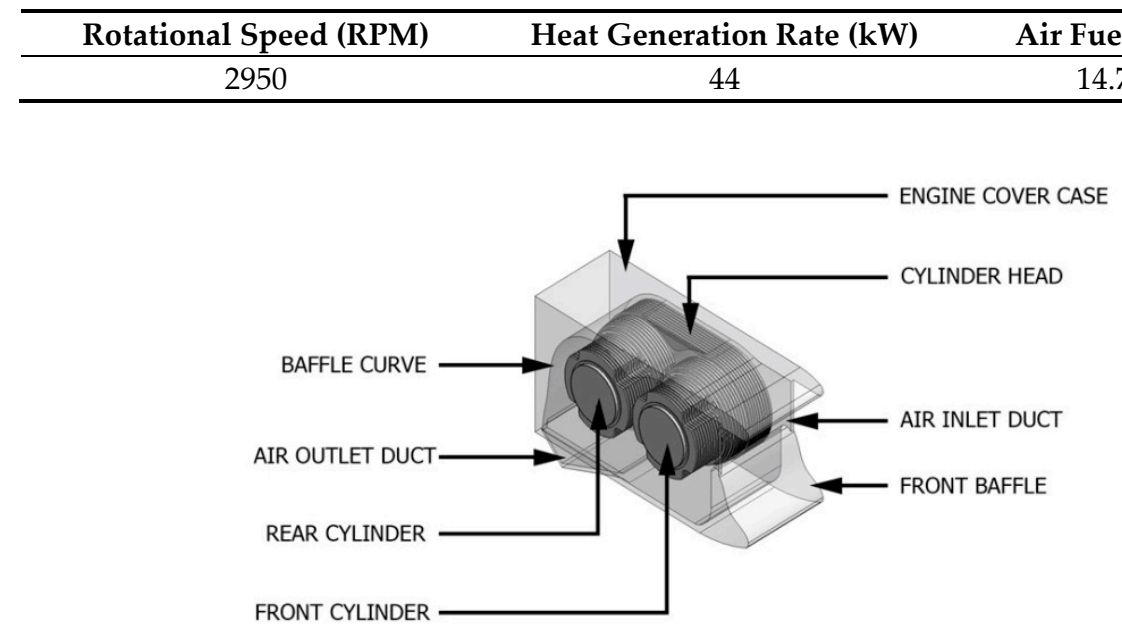

Figure 1. Model assembly descriptions.

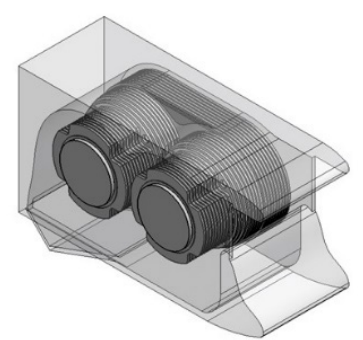

(a)

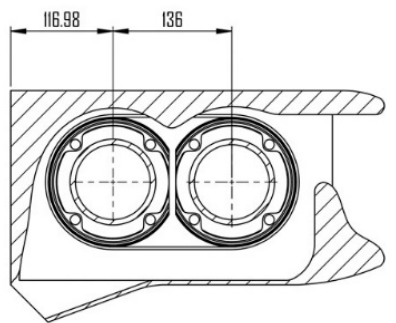

(b)

Figure 2. Model assembly: (a) Isometric view; (b) Side view.

\subsubsection{Shroud and Baffle Plate Model}

Shroud model had made from aluminum sheet as a box model with an inlet at the front for an incoming air to enter. The air outlet was an opening channel underneath which had 20 downward for better scavenging of the air. An internal baffle was modeled from cylinder barrel shape to keep closer distance to engine's finned area for utilizing incoming cold air as possible. Figure 3 are showing the dimension of shroud in mm and internal baffle plate shape (a) and isometric view (b).

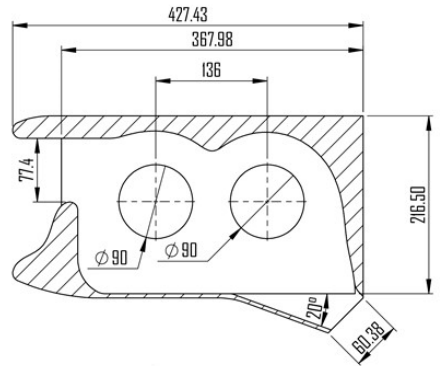

(a)

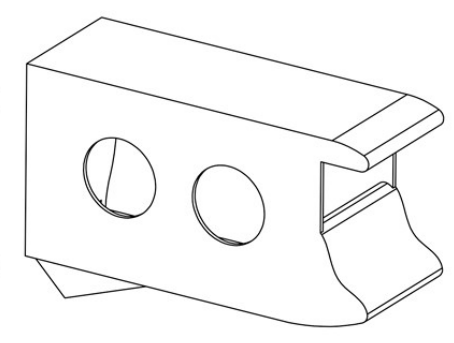

(b)

Figure 3. Shroud and baffle plate: (a) Dimensions; (b) Isometric view.

\section{Results and Discussion}

\subsection{Result from Initial Temperature Condition of $180^{\circ} \mathrm{C}$}

The simulation showed that during cruising speed between 50 to $100 \mathrm{kt}$, assumed that the initial state temperature was $180^{\circ} \mathrm{C}$ which was considered to be normal operating temperature, there was 
a constantly decreasing of temperature with an increasing of airspeed. The result values were taken from the maximum temperature area at the front cylinder barrel, rear cylinder barrel and cylinder head. It was found that front cylinder barrel continually had lower temperature than rear cylinder barrel and cylinder head respectively along the simulated airspeed range. While the airspeed was progressively reducing from $80 \mathrm{kt}$, the cylinder head temperature was increased continuously until reaching temperature of $240{ }^{\circ} \mathrm{C}$ at $60 \mathrm{kt}$. For safe engine operation, $80 \mathrm{kt}$ was the minimum airspeed to operate. Figure 4 is showing graph relationships between front cylinder barrel, rear cylinder barrel, cylinder head temperature $\left({ }^{\circ} \mathrm{C}\right)$ and airspeed $(\mathrm{kt})$ at initial temperature of $180^{\circ} \mathrm{C}$.

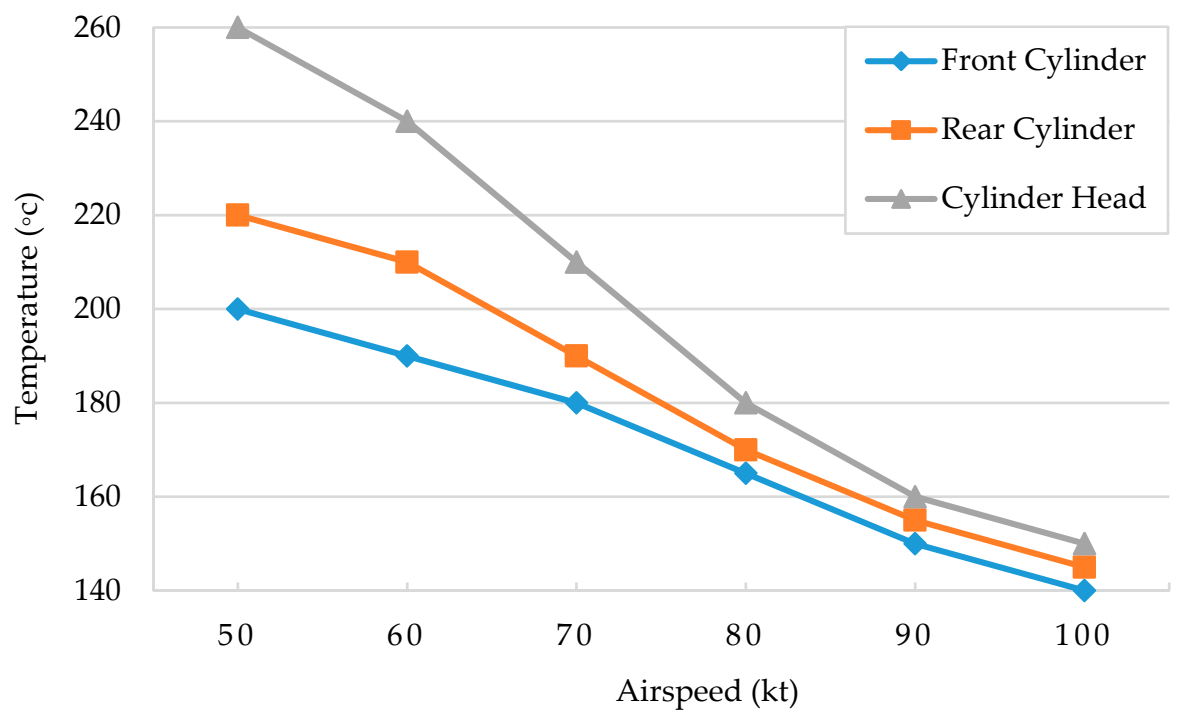

Figure 4. Graph relationships between temperature $\left({ }^{\circ} \mathrm{C}\right)$ and airspeed $(\mathrm{kt})$ at an initial temperature of $180^{\circ} \mathrm{C}$.

Figure $5 \mathrm{a}$ is showing temperature contour of an airspeed of $80 \mathrm{kt}$ simulation. The temperature of cylinder head and barrel are within $180^{\circ} \mathrm{C}$. Figure $5 \mathrm{~b}$ is showing side view of the same result condition. Figure $5 \mathrm{a}, \mathrm{b}$ are also showing temperature range of the internal airflow inside the baffle plate and external airflow.

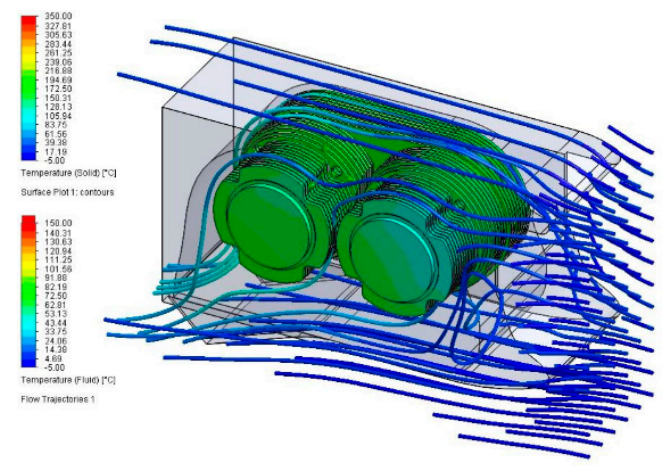

(a)

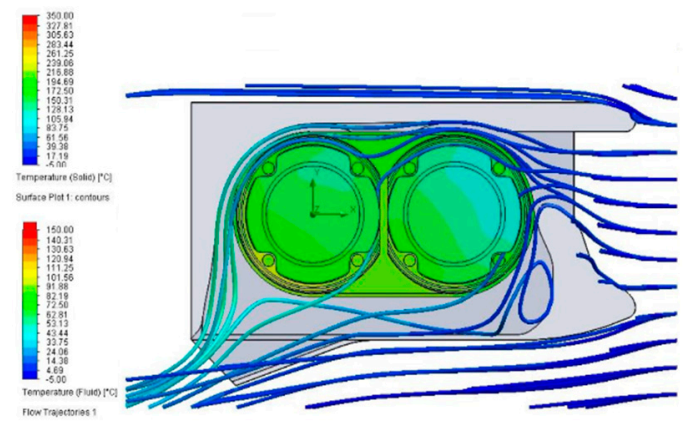

(b)

Figure 5. Simulation result from initial temperature of $180^{\circ} \mathrm{C}$ at $80 \mathrm{kt}$ : (a) Isometric view (b) Side view.

\subsection{Result from Initial Temperature Condition of $240^{\circ} \mathrm{C}$}

The results from an initial $240{ }^{\circ} \mathrm{C}$ simulation showed that all temperatures were also decreased along with an increasing of airspeed as shown in Figure 6. However, these results simulated overheating situation which had not been recovered until reaching an airspeed of $95 \mathrm{kt}$. If there was a situation of an inevitable flight such as climbing, it would not be able to reduce the temperature if the aircraft was not capable of flying straight level flight higher than $95 \mathrm{kt}$. 


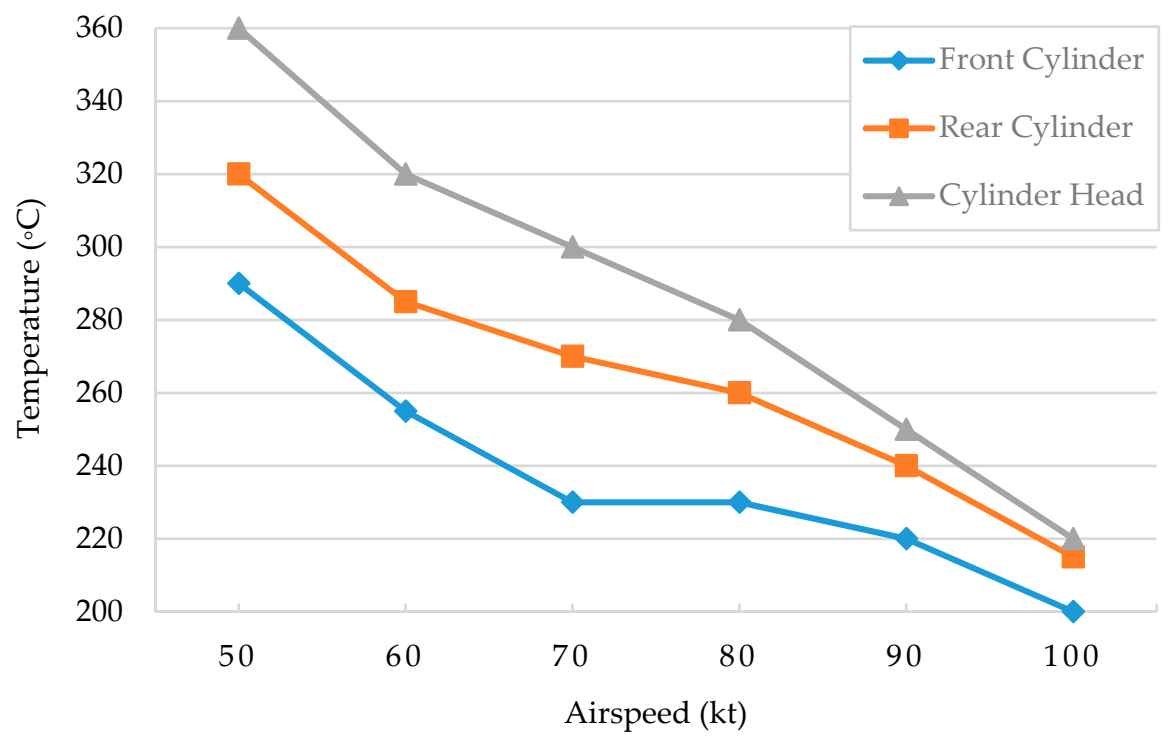

Figure 6. Graph relationships between temperature $\left({ }^{\circ} \mathrm{C}\right)$ and airspeed $(\mathrm{kt})$ at an initial temperature of $240{ }^{\circ} \mathrm{C}$.

Figure 7a is showing temperature contour over cylinder head and barrel of an airspeed of $100 \mathrm{kt}$ simulation. It is also showing temperature range of the internal airflow inside the baffle plate and external airflow. The temperature of cylinder head and barrel are within $220^{\circ} \mathrm{C}$. Figure $7 \mathrm{~b}$ is showing side view of the same result condition.

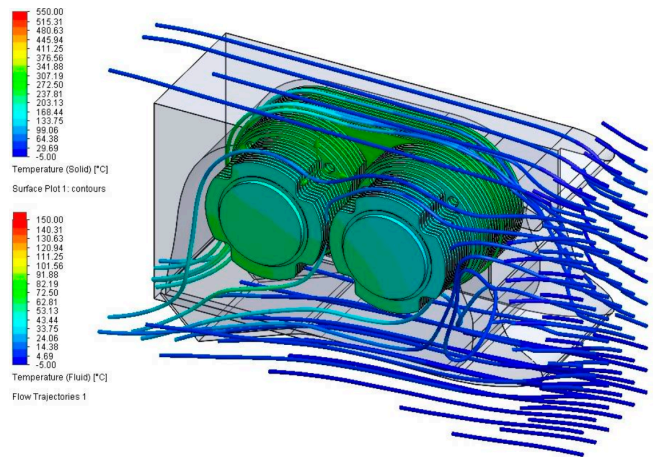

(a)

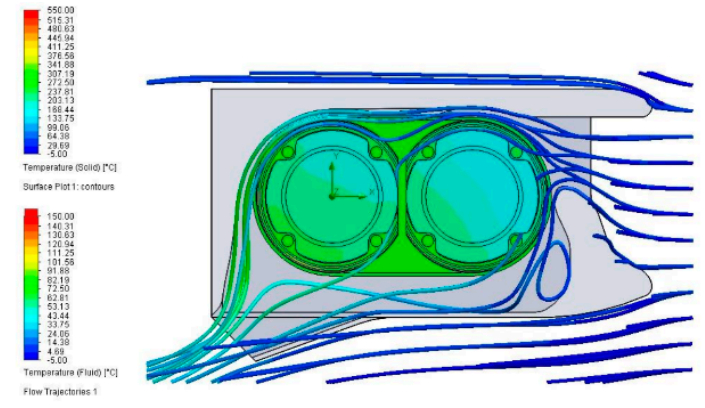

(b)

Figure 7. Simulation result from initial temperature of $240{ }^{\circ} \mathrm{C}$ at $100 \mathrm{kt}$ : (a) Isometric view (b) Side view.

\section{Conclusions}

The VW-Aero conversion engine model with cylinder barrel, cylinder head and baffle plate were simulated at a velocity between $50-100 \mathrm{kt}$. The simulations included both initial temperature of normal operation and overheat conditions. There was a continuously decreasing of temperature with an increasing of airspeed. It can be concluded that rear cylinder barrel and rear area of cylinder head tend to experience higher temperature due to lacking of cooling air from the obstruction of the front cylinder which can lead to an engine overheat problem. For normal operating temperature, the minimum safe engine operation was when flying above $80 \mathrm{kt}(92 \mathrm{mph}$ ) airspeed. Nevertheless, during the situation of an increasing of temperature above normal range, the recovery of heating problem would require above $95 \mathrm{kt}(110 \mathrm{mph})$ of airspeed to ensure the temperature reduction to normal operating temperature. 
Supplementary Materials: The following are available online at http://www.mdpi.com/2504-3900/39/1/4/s1.

Funding: This research received no external funding.

Conflicts of Interest: The authors declare no conflict of interest.

\section{References}

1. Bingelis, T. Firewall Forward: Engine Installation Methods; EAA Aviation Venter: Oshkosh, WI, USA, 2000; pp. 18-33.

2. $\quad$ Freund, K.; Stubblefield, M.; Haynes, J.H. Haynes Repair Manual: VW Beetle E Karmann Ghia; Haynes Repair Manual, Haynes Publishing Group: Somerset, UK, 2016.

3. Haynes, J.H.; Stead, D.M. VW 1300 and 1500 Beetle Owner Workshop Manual; Haynes Publishing Company: Somerset, UK, 1974.

4. Bingelis, T. Engines: Engine Compartment Installations for Sportplane Builders; EAA Aviation Venter: Oshkosh, WI, USA, 2000; pp. 62-89.

5. Kern, T. Hands on Firewall Forward: VW Powerplants. Sport Aviation, February 2010; pp. 92-95.

6. Dye, P. Hummel H5. Kitplanes 2016, 33, 6-13.

7. Wischmeyer, E. Thatcher CX4. Kitplanes 2011, 28, 24-29.

8. Bradley, G. Building the Thatcher CX5. Kitplanes 2016, 33, 6-15.

9. Bradley, G. Introducing the Thatcher CX5. Contact 2014, 107, 3-8.

10. Dye, P. WAIEX-B. Kitplanes 2017, 34, 6-13.

11. Cook, L. ONEX. Kitplanes 2013, 30, 6-13.

12. Spangler, S.M. Building on a Budget. Kitplanes 2011, 28, 17-23.

13. Pietrykowski, K.; Tulwin, T. Aircraft Radial Engine CFD Cooling Model. SAE Int. J. 2015, 8, 82-88, doi:10.4271/2014-01-2884.

14. Taylor, R.E. What about Volkswagen conversion? Sport Aviation, December 1979; pp. 15-18.

15. Taylor, R.E. What about Volkswagen conversion? Part II. Sport Aviation, January 1980; pp. 17-21.

16. Horton, D. Kitplanes 2019 Engine Buyer's Guide. Kitplanes 2019, 36, 22-40.

17. Kitplanes 2020 Homebuilt Aircraft Directory. Kitplanes 2016, 36, 16-61.

(C) 2019 by the authors. Licensee MDPI, Basel, Switzerland. This article is an open access article distributed under the terms and conditions of the Creative Commons Attribution (CC BY) license (http://creativecommons.org/licenses/by/4.0/). 